\title{
TEATER BANGSAWAN MUDA, FORMULA PERTUNJUKAN DRAMA MELAYU BANGSAWAN MASA KINI
}

\author{
Deni Afriadi \\ Pascasarjana Institut Seni Indonesia, Padangpanjang \\ deaf.mtn@gmail.com
}

Abstract

Malay "Bangsawan" drama is believed to the embryo of the development of theatre in Riau province. From its history, Bangsawan drama owed to Indian traders who brought wayang Parsi to Malay Peninsula (Malaysia, Sumatera, and to Temasik (Singapore)). Malay "Bangsawan" drama nowdays undergoes changes. The "Bangsawan" drama changes the existed convention which differentities it from the "old Bangsawan" is then called the "new Bangsawan". This change is beneficial for the continuity of "Malay Bangsawan" drama because a good performance should be able to adapt with the social condition. This writing views how the changes in form and structure occur in Malay "Bangsawan" drama. The changes lead to the term "New (young) Bangsawan Theatre".

Keywords: Malay Bangsawan Drama, New (young) Bangsawan Theatre.

\section{Pendahuluan}

Drama

Melayu

Bangsawan merupakan salah satu teater tradisi yang hidup dan berkembang di Riau selain Mendu, Mamanda, Randai Kuantan dan Makyong. Sejarah perkembangan teater tradisi Bangsawan tidak lepas dari sejarah perdagangan di Tanah Semenanjung Melayu (MalaysiaSumatera) dan Temasik (Singapura) pada abad ke-19.
Bangsa India yang menjelajahi Tanah Semenanjung Melayu dan Temasik, selain menjajakan dagangannya juga membawa hiburan rakyat berupa seni lakonan yang mereka namai Indra Sabor. Dari Indra Saborlah diyakini bahwa cikal-bakalnya hadir Drama Melayu Bangsawan atau lebih dikenal dengan nama teater Bangsawan (Amanriza dan Junus, 1993:96-97). 
Di dalam Kamus Lengkap

Bahasa Indonesia (Anwar, 2003:81), Bangsawan memiliki arti sebagai keturunan orangorang mulia (terutama raja dan kerabatnya). Dapat pula dimaknai sebagai keturunan ningrat dan orang berbangsa. Sementara Rahmah Bujang di dalam buku Sejarah Perkembangan Drama Bangsawan di Tanah Melayu dan Singapura memaparkan bahwasannya perkataan Bangsawan dalam istilah Melayu berasal dari dua kata, yaitu kata bangsa dan wan. Bangsa berarti sekumpulan atau segolongan manusia yang sudah bersatu sebagai kumpulan tertentu, dan wan pula adalah gelaran untuk orang-orang keturunan raja-raja (Bujang, 1975:20).

Merujuk dari pengertian di atas, istilah Bangsawan apabila diaplikasikan kepada seni drama atau teater dapat diartikan sebagai salah satu bentuk seni peran tradisi Melayu yang lakonannya mengetengahkan cerita-cerita kehidupan sekitar kerajaan. Ini dapat pula disimpulkan bahwasannya teater Bangsawan memiliki pola khusus dalam pertunjukkan. Pola tersebut menjadi pengikat sebagai identitas corak pertunjukan.

Ciri khusus teater Bangsawan umumnya mengemukakan kisah-kisah raja/kerajaan, tanpa naskah tertulis, bersifat stylistic, improvisatif dan visualisatif, dialognya campur-aduk bahasa harian, sastra, nyanyian dan diselang-seling dengan tarian. Pementasan dimulakan dengan upacara jampi serapah dan percaya bahwa kekuatan gaib turut menjayakan persembahan (Darmawi, 2005:63).

Dari kutipan di atas, dapat disumpulkan bahwasannya teater Bangsawan adalah sebuah pertunjukan yang menuntut kreatifitas pemerannya. Cerita tidak terikat kepada dialog-dialog baku dari sebuah naskah, namun hanya menyimpulkan konsep 
cerita yang diberikan oleh pengarah. Kekuatan improvisasi dan imajinasi menjadi kemampuan penting dari sang pemeran yang nantinya akan menciptakan dialog-dialog. Selain itu unsur kepercayaan masyarakat terhadap kekuatan gaib masih menjadi bagian dari pertunjukan.

\section{Pola Permainan Teater Bangsawan}

Secara pola pertunjukan, teater Bangsawan dimainkan pada panggung berbentuk proscenium, dimana penonton hanya dapat menyaksikan dari bagian depan panggung. Hal ini berkenaan dengan penggunaan tirai yang menjadi ciri khas pertunjukan. Tirai merupakan kain yang dilukis sedemikian rupa yang tujuannya mewakili gambaran setting lokasi di dalam cerita.

Dalam seni drama bangsawan, olahan teater adalah berasaskan satu corak pentas yang digelar pentas proscenium, yaitu pentas yang mengizinkan penonton menonton dari bagian hadapan sahaja. Ini sama kesannya dengan melihat gambar dalam bingkai. Penggunaan corak pentas proscenium membolehkan pengolahan gambaran set tirai yang elaborate. Dalam bangsawan, pentas sekurangkurangnya mempunyai antara tiga hingga enam tirai asas, mengikuti keperluan cerita, (Bujang, 1989:11).

$$
\text { Penggunaan panggung }
$$
proscenium dan tirai sebagai gambaran suasana lokasi cerita disebabkan teater Bangsawan merupakan lakonan yang memiliki beberapa babak dan episode. Untuk menghadirkan banyak latar dari babak dan episode tersebut maka diwakili dengan gambar lukisan tirai.

Dari penjelasan-penjelasan di atas dapat disimpulkan bahwasannya teater Bangsawan memiliki ciri khusus kesatuan yang tidak dapat dipisahkan. Ciri khusus tersebut, cerita berupa kisah kerajaan; lakonan tanpa teks 
naskah; kekuatan improvisasi aktor; perpaduan dialog harian, sastra dan nyanyian; masih mempercayai kekuatan gaib; dan menggunakan panggung proscenium dan tirai-tirai.

\section{Pembahasan}

\section{A. Drama Melayu Bangsawan Sebagai Landasan Konsep Teater Bangsawan Masa Kini}

$$
\text { Ahmad Darmawi (2005: }
$$

perkembangan Drama Melayu Bangsawan di Riau, siapa yang pertama sekali membawanya tidak ditemukan data secara pasti. Walaupun demikian, sejarah dan perkembangan Drama Melayu Bangsawan di Riau mempunyai hubungan dengan sejarah dan perkembangan Drama Melayu Bangsawan di Semenanjung Tanah Melayu. Embrio mula kedatangan Drama Melayu Bangsawan dibawa oleh Bangsa India pada kisaran abad ke-19. Dari melihat pertunjukan itulah, masyarakat tempatan membuat pertunjukan yang sama dengan latar cerita bernuansa istana sentris kerajaan Melayu.

$$
\text { Drama Melayu }
$$

Bangsawan sempat merajai dunia seni pertunjukan di Semenanjung Melayu pada kisaran tahun 1915. Pada perhelatan dan pertemuan antar raja-raja dan kaum bangsawan di Semenanjung Melayu selalu dihadirkan pertunjukan Drama Melayu Bangsawan. Orang-orang Riau yang menyaksikan pertunjukan tersebut merupakan dari kalangan bangsawan suatu kerajaan atau masyarakat kelas ekonomi menengah ke atas. Dalam kunjungan tersebut, mereka sering menonton berbagai persembahan Drama Melayu Bangsawan. Dari apa yang mereka lihat dan dengar, kemudian muncul keinginan untuk mengembangkan seni pertunjukan Drama Melayu Bangsawan di daerah asal mereka masing-masing. Dorongan ini semakin kuat karena 
dilatarbelakangi oleh kesamaan agama, kesamaan bahasa, persamaan adat istiadat, kesamaan seni budaya serta sebagai media hiburan dan komunikasi dalam menyampaikan maklumat kerajaan (Darmawi, 4 Juni 2018).

Ahmad Darmawi (2005: 74) juga menyebutkan bahwasannya Drama Melayu Bangsawan sebagai teater tradisi memiliki ciri khas dalam pemanggungannya. Di antara ciri khas tersebut adalah bersifat improvisasi, dimana para pelakon cukup mengetahui pokok cerita, selanjutnya terpulang kepada pemeran untuk menghidupkan lakonan dengan kepandaian masing-masing. Selain itu, pemilihan jalan cerita bagi tiaptiap lakon hampir serupa atau sealiran. Kontra dengan gaya modern. Dalam hal ini Drama Melayu Bangsawan sebagai bentuk teater tradisional lebih menekankan kesan pandangan daripada menimbulkan reaksi emosi yang mendalam kepada penonton.

\section{1). Penokohan dalam Drama Melayu Bangsawan}

Perwatakan atau penokohan dalam Drama Melayu Bangsawan atau Teater Bangsawan memiliki ciri khusus. Ahmad Darmawi (2005: 78) menyebutkan penokohan dalam Drama Melayu Bangsawan dibagi menjadi beberapa peringkat. Peringkat pertama merupakan peran tertinggi yang dipegang oleh tokoh Anak Muda, Seri Panggung (Tuan Puteril perempuan muda yang cantik) dan Khadam (ahli lawak). Perwatakan diperingkat pertama ini merupakan tokoh protagonis yang menjadi tokoh utama dalam cerita.

$$
\text { Peringkat kedua }
$$
diperankan oleh tokoh Raja, Permaisuri, Para Menteri dan Raja Jin. Tokoh ini dikategorikan sebagai pemeran pembantu utama. Keberadaannya sangat penting 
dalam suatu pementasan karena menjadi dasar penghubung dalam cerita Teater Bangsawan.

Peringkat ketiga diperakan oleh para menteri kerajaan. Pemeran ini sebagai pemeran pembantu atau dalam istilah Drama Melayu Bangsawan disebut denga Anak Mambang. Perwatakan ini biasanya memerankan tokoh Datuk Bendahara, Mamanda Menteri, Mamanda Wazir, Datuk Panglima, Orang Pertapaan dan Nenek Kabayan.

$$
\text { Peringkat keempat }
$$
merupakan peran pelengkap saja yang dalam istilah Drama Melayu Bangsawan disebut Pak Pacak. Biasanya diperankan oleh Pengawal, Hulu Balang dan Dayang-dayang. Tugasnya hanya berdiri di samping Raja atau permaisuri sambil memegang tombak atau kipas. Sementara diperingkat kelima adalah peran penambahan jika memang diperlukan. Tokoh ini antara lain
Ahli Nujum (peramal), Bintara, Lanon, Rakyat Jelata.

\section{2). Pakaian dan Hiasan Pelakon Drama Melayu Bangsawan}

Salah satu ciri khusus dari Drama Melayu Bangsawan adalah penggunaan pakaian dan hiasan. Ahmad Darmawi (2005: 83) menerangkan bahwa dalam penggunaan pakaian tokoh Seri Panggung lah yang melebihi pakaian para pelakon lainnya. Biasanya, Seri Panggung memakai baju kurung kebaya labuh yang terbuat dari bahan kain berkilat serta berwarna cerah dilengkapi pula dengan perhiasan sehingga menarik pandangan mata. Pakaian dan perhiasaan Seri Panggung ini meskipun divariasikan dengan berbagai model tetapi tetap terikat pada norma adat dan syara' segingga menimbulkan kesan elok rupa, elok pakaian, elok pula perangainya.

$$
\text { Untuk pelakon Anak Muda }
$$

selain mengikut bawaan peran, 
mesti memakai baju kurung Melayu. Jika keturunan raja, pakaian harus menggambarkan kebesaran dan kemuliaan. Sementara pakaian Khadam, selain menggunakan pola baju kurung, modelnya diperunik dengan warna yang beraneka ragam atau berbelang dengan rias wajah yang menimbulkan efek lucu.

Pakaian Raja mestilah menggambarkan kebesaran dan keagungan dengan baju Teluk Belanga didominasi kuning keemasan. Selain itu pakaian raja harus menunjukkan tanda-tanda kebesarannya, seperti tanjak, keris dan selempang. Pemeran para Menteri juga memakai baju kurung kebesaran Melayu sesuai dengan peran dan kedudukannya. Untuk Panglima beserta bawahannya, Bintara Kanan maupun Kiri serta Hulubalang juga memakai baju kurung Melayu dengan umumnya didominasi hitam. Raja Jin ditetapkan dengan pakaian bersayap dengan solekan yang menunjukkan kekerasan dan kekasarannya. Sedang pelakon lainnya tetap berpakaian Melayu dengan bentuk dan warna serta kelengkapannya sesuai kebutuhan.

\section{3). Sastra, Musik, Tari dan Lagu dalam Drama Melayu Bangsawan}

Aspek seni sastra dalam Drama Melayu Bangsawan merupakan unsur utama, karena selain dialognya menggunakan bahasa Melayu yang indah, di dalam dialog juga banyak terdapat pantun, seloka, syair dan pepatah. Ahmad Darmawi (2005: 86) memaparkan pada mulanya alatalat musik yang digunakan dalam pertunjukan Drama Melayu Bangsawan hanyalah alat-alat musik tradisi bernuansa Melayu seperti gebano, marwas, tum-tum, kompang, gong/canang/tetawak, seruing, oud/gambus ditambah dengan beberapa alat musik India seperti tabla, harmonium dan dol. 
Dalam pertunjukan Drama Melayu Bangsawan, keberadaan musik mempunyai peran penting antara lain, sebagai musik pembuka pergantian babak serta penutup dengan irama Sangga Buana dan mengiring irama syair Selendang Delima. Selain itu musik juga berfungsi sebagai pengiring lagu nyanyi-nyanyian, pengiring tarian, mengisi kekosongan dialog, tekanan dialog maupun membangun suasana. Irama-irama Melayu yang pada umumnya dibawakan merupakan irama Inang, Langgam, Joget, Zapin, Dondang dan Gazal.

\section{4). Panggung/ Pentas Drama Melayu Bangsawan}

Untuk set dekorasi panggung Teater Bangsawan memiliki ciri khas tersendiri dalam pemanggungannya. Adapun ciri khas tersebut adalah penggunaan layar tirai sebagai penggambaran lokasi kejadian yang pada pertunjukan teater sekarang disebut dengan setting. Rahmah Bujang (1989: 11) menyebutkan, dalam seni drama Bangsawan, olahan teater adalah berasaskan satu corak pentas yang digelar pentas proscenium, yaitu pentas yang mengizinan penonton menyaksikan dari bagian depan saja. Ini sama kesannya dengan melihat gambar dalam bingkai.

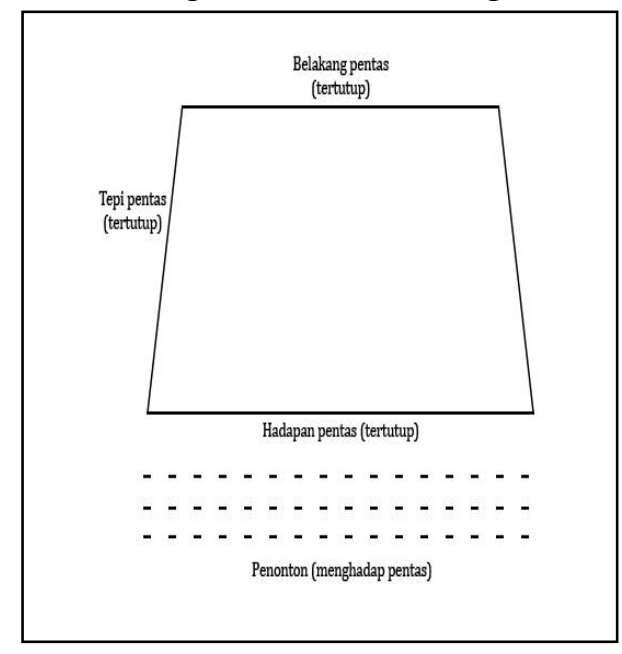

Gambar 1. Bentuk panggung pertunjukan Teater Bangsawan, Rahmah Bujang (1989: 12)
Sementara penggunaan
corak pentas proscenium membolehkan pengolahan gambaran set tirai yang elaborate. Dalam Drama Melayu Bangsawan, pentas sekurang- kurangnya mempunyai antara tiga 
hingga enam tirai asas, mengikut keperluan cerita. Set tirai yang menjadi asas pentas Drama Melayu Bangsawan mengikuti adegan cerita. Eman tirai tersebut terbagi menjadi: (a) set tirai pemandangan dalam ruang istana, (b) set tirai pemandangan jalan raya, (c) set tirai pemandangan dalam hutan, (d) set tirai pemandangan dalam sebuah taman, (e) set tirai pemandangan dalam ruang bilik, (f) set tirai pemandangan alam.

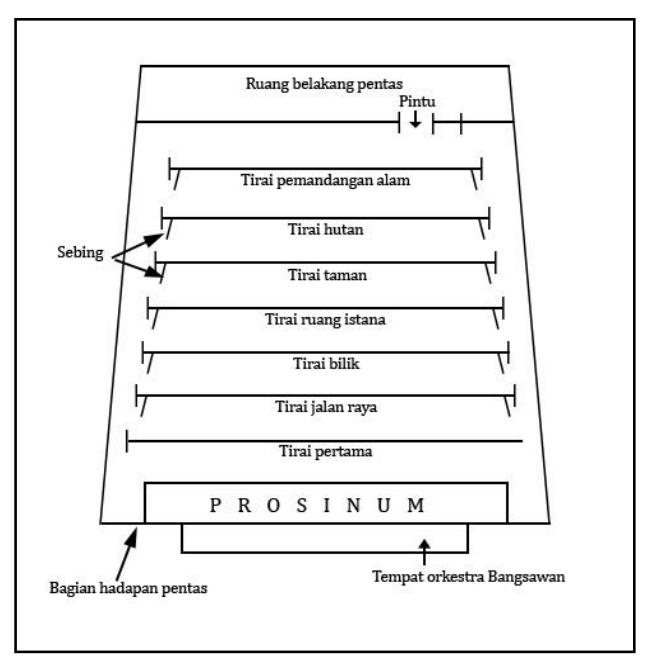

Gambar 2. Susunan set tirai, Rahmah Bujang (1989: 14)

Ahmad Darmawi (2005: 88-89) menerangkan ukuran panggung yang umumnya digunakan pada pertunjukan Drama Melayu Bangsawan terbagi menjadi tiga kelompok, berdasarkan konsep dari setiap kumpulan (grup sanggar). Besaran yang pertama merupakan dari kalangan pentas kumpulan kecil yang anggotanya berkisar 30 orang. Pentas biasanya berukuran lebar 8 meter, pajang 9 meter dan tinggi 4 meter dengan tirai berjumlah 6 layar.

Untuk pentas kumpulan besar umumnya memiliki anggota sekitar 100 orang dengan melakukan pementasan di bandarbandar besar yang telah memiliki gedung. Kalaupun tidak ada gedung, mereka membangun pentas yang peralatannya sudah tersedia (bongkar pasang). Ukuran pentas dari kumpulan besar ini umumnya memiliki lebar 12 meter, panjang 18 meter dan tinggi 7,5 meter dengan jumlah tirai sebanyak 20 layar.

Pentas kumpulan besar dan masyur memiliki ukuran pentas tidak jauh dari kumpulan besar. Hanya saja, kumpulan 
besar dan masyur ini memiliki peralatan dan perlengkapan pentas sendiri untuk pertunjukan sekaligus penonton (seperti pentas tenda sirkus pada masa sekarang). Pementasan dari kumpulan besar dan masyur ini mampu menampung penonton sebanyak 600an orang yang tempat duduknya terbagi menjadi tiga bagian. Kelas I dengan kapasitas 100 orang, kelas II 200 orang dan kelas III sebanyak 300 orang. Jumlah anggota dari kumpulan besar dan masyur ini sekitar 150 orang. Di antara kumpulan besar dan masyur yang pernah merajai Drama Melayu Bangsawan pada masanya adalah kumpulan Kinta Opera pimpinan Cik Nasir dan Indera Bangsawan pimpinan Siti Hawa.

\section{B. Teater Bangsawan Muda, Formula Teater Bangsawan Kekinian \\ Nama Teater Bangsawan}

Muda mulai mencul pada kisaran tahun 80-an di Riau. Istilah tersebut diberikan kepada pertunjukan-pertunjukan teater Bangsawan yang sudah memadupadankan teater Bangsawan dengan teknik pemanggungan teater Barat. Salah satunya adalah meninggalkan penggunaan tirai di dalam pertunjukannya.

Di dalam bukunya, Ahmad Darmawi (2005: 144) mengatakan bahwa yang dimaksud dengan Teater Bangsawan Muda adalah seni persembahan/ pertunjukan teater tradisi atau drama klasik yang masih membawa sebagian unsur, pola dan bentuk Teater Bangsawan Tua (Drama Melayu Bangsawan). Masyarakat pendukung Teater Bangsawan Muda di Riau adalah masyarakat di wilayah little tradition yang jauh dari wilayah pusat kerajaan. Adapun ciri-ciri pola dan bentuk Teater Bangsawan Muda di Riau dapat digambarkan sebagai berikut: (a) Menggunakan naskah, (b) Cerita klasik, (c) Tokoh semi stock type, (d) Pelakon terdiri dari 
lelaki dan perempuan, (e) pengenalan pelakon semi/ tanpa tablo, (f) jumlah babak terbatas, (g) sedikit atau tanpa layar, (h) musik, lagu, syair dan tari tidak dominan, (i) pola dan bentuk pementasan sudah modern.

\section{Simpulan}

Dari uraian di atas, dapat disimpulkan bahwa Drama Melayu Bangsawan atau yang lebih dikenal dengan Teater Bangsawan merupakan salah satu pertunjukan teater tradisi yang hidup dan berkembang di Riau selain Mendu, Mamanda, Randai Kuantan dan Makyong. Sejarah perkembangan teater tradisi Bangsawan tidak lepas dari sejarah perdagangan di Tanah Semenanjung Melayu (MalaysiaSumatera) dan Temasik (Singapura) pada abad ke-19. Bangsa India yang menjelajahi Tanah Semenanjung Melayu dan Temasik, selain menjajakan dagangannya juga membawa hiburan rakyat berupa seni lakonan yang mereka namai Indra Sabor. Dari Indra Saborlah diyakini bahwa cikal-bakalnya hadir Drama Melayu Bangsawan. Secara pola pertunjukan, teater Bangsawan dimainkan pada panggung berbentuk proscenium, dimana penonton hanya dapat menyaksikan dari bagian depan panggung. Hal ini berkenaan dengan penggunaan tirai yang menjadi ciri khas pertunjukan. Tirai merupakan kain yang dilukis sedemikian rupa yang tujuannya mewakili gambaran setting lokasi di dalam cerita.

Nama Teater Bangsawan Muda mulai mencul pada kisaran tahun 80-an di Riau. Istilah tersebut diberikan kepada pertunjukan-pertunjukan teater Bangsawan yang sudah memadupadankan teater Bangsawan dengan teknik pemanggungan teater Barat. Salah satunya adalah meningalkan penggunaan tirai di dalam pertunjukannya. Namun hingga saat ini, pengelompokan teater 
Bangsawan dan Bangsawan Muda

masih diabaikan oleh pelakupelaku teater dan masyarakat Riau.

\section{Daftar Pustaka}

Amanriza, Ediruslan Pe. dkk. 1993. Seni Pertunjukan Tradisional (teater rakyat) Daerah Riau. Pekanbaru: Departemen Pendidikan Provinsi Riau.

Bujang, Rahmah. 1989. Seni

Persembahan Bangsawan.

Kuala Lumpur: Dewan

Bahasa dan Pustaka

Kementerian Pendidikan

Malaysia.
Dharmawi, GP. Ade. 2005. Teater Bangsawan Melayu Riau. Pekanbaru: Lembaga Seni Budaya Melayu Sultan Teater Riau (LSMB-STR).

\section{Informan}

GP Ade Dharmawi (63 tahun), pembina Sanggar Latah Tuah Pekanbaru sekaligus tokoh Teater Bangsawan di Riau. 